\title{
ANALISIS OVERLAY UNTUK MENENTUKAN POTENSI SEKTOR EKONOMI UNGGULAN DALAM PEMBANGUNAN DAERAH (Studi Kasus dengan PDRB Kota Pontianak)
}

\author{
Dini Adiyatin, Neva Satyahadewi, Hendra Perdana
}

\begin{abstract}
INTISARI
Penentuan sektor unggulan pada sektor perekonomian di Kota Pontianak dapat diketahui dari hasil analisis Overlay. Tujuan penelitian ini untuk mengetahui sektor lapangan usaha yang unggul khususnya di Kota Pontianak dengan Kalimantan Barat sebagai wilayah referensi. Penelitian ini menggunakan analisis Overlay yang merupakan penggabungan hasil metode Location Quotient, Dynamic Location Quotient dan Model Rasio Pertumbuhan. Data yang digunakan adalah data PDRB atas dasar harga konstan dengan wilayah studi Kota Pontianak dan wilayah referensi Kalimantan Barat tahun 2012-2016. Proses perhitungan analisis Overlay menggabungkan informasi hasil perhitungan yang mendeskripsikan gambaran pertumbuhan, peranan serta kontribusi, potensi dari masing-masing sektor lapangan usaha di Kota Pontianak. Hasil penelitian menunjukkan bahwa sektor-sektor lapangan usaha di Kota Pontianak selama kurun waktu 5 tahun secara garis besar mengalami pertumbuhan. Sektor lapangan usaha yang paling unggul di Kota Pontianak adalah sektor pengadaan air, pengelolaan sampah, limbah dan daur ulang yang tumbuh cepat sebesar 2,55\% dengan menyumbang kontribusi rata-rata di Kalimantan Barat sebesar 2,78\% dan sektor jasa kesehatan dan kegiatan sosial yang tumbuh cepat sebesar 0,76\% dengan menyumbang kontribusi rata-rata di Kalimantan Barat sebesar 1,19\%.
\end{abstract}

Kata Kunci: Analisis Overlay, PDRB, Sektor Unggul.

\section{PENDAHULUAN}

Pembangunan nasional adalah usaha dalam menciptakan pertumbuhan ekonomi dan pemerataan pembangunan, termasuk didalamnya pemerataan pendapatan antar daerah. Sasaran pembangunan dapat dicapai dengan perencanaan ekonomi yang baik. Perencanaan ekonomi yang baik berdampak pada pembangunan ekonomi di daerah. Pembangunan ekonomi daerah berkaitan erat dengan potensi ekonomi, serta karakteristik yang dimiliki oleh setiap daerah[3]. Salah satu indikator penting untuk mengetahui potensi ekonomi di suatu daerah dalam suatu periode tertentu adalah data PDRB (Produk Domestik Regional Bruto). PDRB merupakan jumlah dari nilai barang dan jasa akhir yang dihasilkan oleh seluruh unit ekonomi suatu daerah. PDRB ADHK menunjukkan nilai tambah barang dan jasa yang dihitung menggunakan harga berlaku pada waktu tertentu sebagai tahun dasar. PDRB ADHK (Atas Dasar Harga Konstan) digunakan untuk mengetahui pertumbuhan ekonomi secara riil dari tahun ke tahun atau pertumbuhan ekonomi yang tidak dipengaruhi oleh faktor harga[6].

Analisis sektor basis dapat menjadi alat bantu yang sangat penting dalam memberikan gambaran tentang sektor-sektor potensial yang cepat berkembang, konsentrasi dan arah sektor pembangunan. Analisis sektor basis dilakukan dengan membandingkan angka pertumbuhan suatu sektor lapangan usaha dalam kurun waktu tertentu, pada penelitian ini menggunakan kurun waktu 5 tahun yang disesuaikan dengan masa jabatan, evaluasi serta pembaruan kebijakan di suatu wilayah pemerintahan kota. Hasil analisis sektor basis memberikan gambaran serta masukan kepada Pemerintah Daerah untuk perencanaan kebijakan strategis yang lebih efektif dan efisien.

Penelitian dilakukan dengan mengumpulkan data PDRB menurut lapangan usaha atas dasar harga konstan Kota Pontianak dan Provinsi Kalimantan Barat tahun 2012 sampai dengan 2016. Tujuan dalam penelitian ini untuk mengetahui penjabaran pola dan struktur pertumbuhan serta menentukan sektor ekonomi unggulan wilayah studi Kota Pontianak berdasarkan laju pertumbuhan PDRB, besar pendapatan dan kontribusi sektor ekonomi dengan pembanding Kalimantan Barat sebagai wilayah 
referensi. Batasan masalah penelitian ini difokuskan untuk menentukan sektor ekonomi yang paling unggul di Kota Pontianak yang didapat dari hasil analisis Overlay.

Analisis Overlay terdiri dari beberapa tahap, yaitu klasifikasi Typology Klassen, analisis Location Quotient, analisis Dynamic Location Quotient, analisis Model Rasio Pertumbuhan dan Shift Share. Hasil analisis Overlay menentukan sektor unggulan dengan mempertimbangkan kriteria pertumbuhan dan kontribusi suatu sektor hingga dapat ditentukan sebagai sektor perekonomian yang layak dikembangkan dan memiliki peranan penting terhadap perekonomian di Provinsi Kalimantan Barat.

\section{PRODUK DOMESTIK REGIONAL BRUTO (PDRB)}

PDRB didefinisikan sebagai jumlah nilai tambah yang dihasilkan oleh seluruh unit usaha dalam suatu wilayah atau merupakan jumlah seluruh nilai barang dan jasa akhir yang dihasilkan oleh seluruh unit ekonomi di suatu wilayah[2]. Penyusunan PDRB dapat dilakukan melalui tiga pendekatan yaitu pendekatan produksi, pengeluaran, dan pendapatan yang disajikan atas dasar harga berlaku dan harga konstan. PDRB atas dasar harga berlaku disusun berdasarkan harga yang berlaku pada periode perhitungan, dan bertujuan untuk melihat struktur perekonomian. PDRB atas dasar harga konstan disusun berdasarkan harga pada tahun dasar dan bertujuan untuk mengukur pertumbuhan ekonomi. Besarnya nilai PDRB yang dihasilkan oleh setiap kabupaten/kota selain tergantung dari investasi yang ditanamkan di masing-masing daerah, juga sangat dipengaruhi sumber daya manusia daerah yang bersangkutan.

Perhitungan PDRB secara konseptual menggunakan tiga macam pendekatan, yaitu pendekatan produksi, pendekatan pengeluaran dan pendekatan pendapatan. PDRB dengan pendekatan produksi disajikan dalam 17 sektor lapangan usaha. PDRB menurut lapangan usaha digunakan untuk mengetahui kondisi perekonomian dan menentukan sektor unggulan. PDRB menurut lapangan usaha dirinci menurut total nilai tambah dari seluruh sektor ekonomi. PDRB lapangan usaha mencakup Pertanian, Kehutanan dan Perikanan; Pertambangan dan Penggalian; Industri Pengolahan; Pengadaan Listrik dan Gas; Pengadaan Air, Pengelolaan Sampah, Limbah dan Daur Ulang; Konstruksi; Perdagangan Besar dan Eceran, Reparasi Mobil dan Sepeda Motor; Transportasi dan Pergudangan; Penyediaan Akomodasi dan Makan Minum; Informasi dan Komunikasi; Jasa Keuangan; Real Estate; Jasa Perusahaan; Administrasi Pemerintahan, Pertahanan dan Jaminan Sosial Wajib; Jasa Pendidikan; Jasa Kesehatan dan Kegiatan Sosial Wajib; dan Jasa Lainnya.

\section{KLASIFIKASI TYPOLOGY KLASSEN}

Klasifikasi Typology Klassen digunakan untuk mengetahui gambaran tentang pola dan struktur pertumbuhan masing-masing sektor ekonomi. Pola dan struktur pertumbuhan daerah dapat dipergunakan untuk memperkirakan prospek pertumbuhan ekonomi daerah pada masa mendatang[3]. Typology Klassen diperlukan oleh daerah untuk pengambilan kebijakan dalam pengembangan sektor usaha dalam perekonomian daerah sehingga pendapatan atau produksi daerah dapat meningkat dan target pertumbuhan ekonomi dapat tercapai.

Tabel 1 Klasifikasi Typology Klassen

\begin{tabular}{|c|c|c|}
\hline $\begin{array}{c}\text { Laju } \\
\text { Pertumbuhan }\end{array}$ & $y_{i j}>y_{i R}$ & $y_{i j}<y_{i R}$ \\
\hline$g_{i j}>G_{i R}$ & $\begin{array}{c}\text { Kontribusi } \\
\text { Sektor tumbuh cepat }\end{array}$ & $\begin{array}{c}\text { Kuadran 3 } \\
\text { Sektor sedang tumbuh }\end{array}$ \\
\hline$g_{i j}<G_{i R}$ & $\begin{array}{c}\text { Kuadran 2 } \\
\text { Sektor tertekan }\end{array}$ & $\begin{array}{c}\text { Kuadran 4 } \\
\text { Sektor relatif tertinggal }\end{array}$ \\
\hline
\end{tabular}

Hasil analisis Typology Klassen, mengklasifikasikan sektor-sektor ekonomi yang mempunyai karakteristik berbeda dalam empat bagian yaitu:

a. Kuadran 1. Sektor tumbuh cepat (rapid growth sector) adalah sektor di wilayah studi yang memiliki laju pertumbuhan ekonomi $\left(g_{i j}\right)$ dan kontribusi $\left(y_{i j}\right)$ yang tinggi di wilayah referensi. 
b. Kuadran 2. Sektor tertekan (retarded sector) adalah sektor yang memiliki laju pertumbuhan yang rendah di wilayah studi $\left(g_{i j}\right)$, namun memiliki kontribusi $\left(y_{i j}\right)$ yang besar di wilayah referensi.

c. Kuadran 3. Sektor sedang tumbuh (growing sector) adalah sektor yang memiliki laju pertumbuhan $\left(g_{i j}\right)$ yang tinggi di wilayah referensi, namun memiliki kontribusi $\left(y_{i j}\right)$ yang rendah di wilayah referensi.

d. Kuadran 4. Sektor relatif tertinggal (relatively backward sector) adalah sektor di wilayah studi yang memiliki laju pertumbuhan $\left(g_{i j}\right)$ dan kontribusi $\left(y_{i j}\right)$ yang rendah yang rendah di wilayah referensi.

\section{ANALISIS LOCATION QUOTIENT (LQ)}

Analisis $L Q$ adalah metode yang membandingkan porsi lapangan kerja/ jumlah produksi/ nilai tambah untuk sektor tertentu di suatu wilayah dibandingkan dengan porsi lapangan kerja/ jumlah produksi/ nilai tambah untuk sektor yang sama secara nasional. Tujuan analisis $L Q$ untuk mengidentifikasi sektor unggulan dalam suatu wilayah[3]. Rumus menghitung $L Q$ adalah:

$$
L Q=\frac{\left(v_{i j} / v_{i j t o t}\right)}{\left(V_{i R} / V_{i R t o t}\right)}
$$

$v_{i j}$ adalah pendapatan sektor ekonomi $i$ di Kota Pontianak, $v_{i j t o t}$ adalah pendapatan total PDRB di Kota Pontianak, $V_{i R}$ adalah pendapatan sektor ekonomi $i$ di Kalimantan Barat, dan $V_{\text {iRtot }}$ adalah pendapatan total PDRB di Kalimantan Barat.

Hasil perhitungan analisis $L Q$ dibagi menjadi tiga kriteria, yaitu:

a. Jika nilai $L Q>1$, maka sektor yang bersangkutan merupakan sektor unggulan atau basis.

b. Jika nilai $L Q=1$, maka sektor yang bersangkutan hanya cukup memenuhi kebutuhan daerah lokal.

c. Jika $L Q<1$, maka sektor yang bersangkutan kurang dominan dibanding sektor yang sama di tingkat daerah tertentu, sehingga bukan merupakan sektor unggulan atau non basis.

Kelemahan $L Q$ adalah bahwa kriteria ini bersifat statis yang hanya memberikan gambaran pada satu titik waktu yakni bahwa potensi suatu sektor unggulan atau basis belum tentu akan menjadi sektor unggulan di waktu yang akan datang, sebaliknya sektor yang belum unggul pada saat ini mungkin akan unggul di masa yang akan datang. Mengatasi kelemahan $L Q$ sehingga dapat diketahui perubahan atau reposisi sektoral digunakan varians dari $L Q$ disebut Dynamic Location Quotient.

\section{ANALISIS DYNAMIC LOCATION QUOTIENT (DLQ)}

Analisis $D L Q$ digunakan untuk mengetahui seberapa besar perubahan yang terjadi dalam suatu sektor perekonomian di suatu daerah dan bagaimana perkembangan sektor perekonomian tersebut dengan cara membandingkan dengan sektor yang sama di tingkat wilayah yang lebih luas sebarannya[4]. Rumus menghitung $D L Q$ sebagai berikut[5]:

$$
\begin{aligned}
& D L Q=\frac{\left(v_{i j 0}\left(1+g_{i j}\right)^{t} / v_{i j t o t 0}\left(1+G_{i j}\right)^{t}\right)}{\left(V_{i R 0}\left(1+g_{i R}\right)^{t} / V_{i R t o t 0}\left(1+G_{i R}\right)^{t}\right)} \\
& D L Q=\left(\frac{\left(1+g_{i j}\right) /\left(1+G_{i j}\right)}{\left(1+g_{i R}\right) /\left(1+G_{i R}\right)}\right)^{t}
\end{aligned}
$$

Laju pertumbuhan sektor ekonomi $i$ di Kota Pontianak dinotasikan dengan $g_{i j}, G_{i j}$ adalah rata-rata laju pertumbuhan PDRB sektor ekonomi $i$ di Kota Pontianak, $g_{i R}$ adalah laju pertumbuhan sektor 
ekonomi $i$ di Kalimantan Barat, $G_{i R}$ adalah rata-rata laju pertumbuhan PDRB sektor ekonomi $i$ di Kalimantan Barat, dan $t$ adalah tahun penelitian.

Terdapat tiga kriteria hasil perhitungan analisis $D L Q$, yaitu:

a. $D L Q>1$ dengan kriteria (+), maka potensi perkembangan sektor yang bersangkutan di Kota Pontianak lebih cepat dibandingkan sektor yang sama di Kalimantan Barat. Sektor tersebut masih dapat diharapkan untuk menjadi sektor basis di masa mendatang.

b. $D L Q=1$ dengan kriteria (+), maka potensi perkembangan sektor yang bersangkutan terhadap potensi peningkatan PDRB Kota Pontianak sama dengan pertumbuhan suatu sektor di Kalimantan Barat.

c. $D L Q<1$ dengan kriteria (-), maka potensi perkembangan sektor yang bersangkutan di Kota Pontianak lebih lambat dibandingkan sektor yang sama di Kalimantan Barat. Sektor tersebut tidak dapat diharapkan untuk menjadi sektor basis di masa mendatang.

\section{MODEL RASIO PERTUMBUHAN (MRP)}

Model Rasio Pertumbuhan untuk melihat deskripsi kegiatan atau sektor ekonomi yang potensial berdasarkan pada kriteria pertumbuhan struktur ekonomi wilayah baik eksternal maupun internal[3]. Pendekatan analisis MRP dibagi menjadi dua, yaitu Rasio Pertumbuhan Referensi $\left(R P_{R}\right)$ dan Rasio Pertumbuhan Wilayah Studi $\left(R P_{S}\right)$, dimana wilayah referensi adalah Provinsi Kalimantan Barat dan wilayah studi adalah Kota Pontianak.

1. Rasio Pertumbuhan Referensi $\left(R P_{R}\right)$

Rasio Pertumbuhan Referensi adalah perbandingan antara laju pertumbuhan pendapatan sektor ekonomi $i$ di wilayah referensi dengan laju pertumbuhan total PDRB wilayah referensi. Dirumuskan sebagai berikut[6]:

$$
R P_{R}=\frac{\Delta E_{i R} / E_{i R,(t-1)}}{\Delta E_{R} / E_{R,(t-1)}}
$$

Perubahan pendapatan PDRB sektor ekonomi $i$ di Kalimantan Barat dinotasikan dengan $\Delta E_{i R}, E_{i R,(t-1)}$ adalah pendapatan sektor ekonomi $i$ di Kalimantan Barat pada tahun awal penelitian, $\Delta E_{R}$ adalah perubahan totalan PDRB di Kalimantan Barat, dan $E_{R,(t-1)}$ adalah totalan PDRB Kalimantan Barat pada tahun awal penelitian.

Jika $R P_{R} \geq 1$ dengan kriteria (+), menunjukkan bahwa pertumbuhan suatu sektor tertentu dalam wilayah referensi lebih tinggi dari pertumbuhan PDRB total wilayah referensi. Jika $R P_{R}<1$ dengan kriteria (-), menunjukkan bahwa pertumbuhan suatu sektor tertentu dalam wilayah referensi lebih kecil dari pertumbuhan PDRB total wilayah referensi.

2. Rasio Pertumbuhan Wilayah Studi $\left(R P_{S}\right)$

Rasio Pertumbuhan Wilayah Studi adalah perbandingan antara laju pertumbuhan sektor ekonomi $i$ wilayah studi dengan laju pertumbuhan sektor ekonomi $i$ wilayah referensi. Dirumuskan sebagai berikut[6]:

$$
R P_{S}=\frac{\Delta E_{i j} / E_{i j,(t-1)}}{\Delta E_{i R} / E_{i R,(t-1)}}
$$

Perubahan pendapatan sektor ekonomi $i$ di Kota Pontianak dinotasikan dengan $\Delta E_{i j}, E_{i j,(t-1)}$ adalah pendapatan sektor ekonomi $i$ di Kota Pontianak pada tahun awal penelitian, $\Delta E_{i R}$ adalah perubahan pendapatan sektor ekonomi $i$ di Kota Pontianak pada tahun awal penelitian, dan $E_{i R,(t-1)}$ adalah pendapatan sektor ekonomi $i$ di Kalimantan Barat pada tahun awal penelitian. 
Jika nilai $R P_{S} \geq 1$ dengan kriteria (+), menunjukkan bahwa pertumbuhan sektor pada tingkat wilayah studi lebih tinggi dibandingkan dengan pertumbuhan sektor pada wilayah referensi. Jika nilai $R P_{S}<1$ dengan kriteria (-), menunjukkan bahwa pertumbuhan suatu sektor pada tingkat wilayah studi lebih rendah dibandingkan dengan pertumbuhan sektor pada wilayah referensi.

Hasil dari analisis MRP diklasifikasikan sebagai berikut:

a. Klasifikasi 1, yaitu nilai $R P_{R}(+)$ dan $R P_{S}(+)$ berarti sektor tersebut pada wilayah referensi mempunyai pertumbuhan yang menonjol dan demikian pula pada wilayah studi. Kegiatan ini selanjutnya disebut dominan pertumbuhan.

b. Klasifikasi 2, yaitu nilai $R P_{R}(+)$ dan $R P_{S}(-)$ berarti kegiatan tersebut pada wilayah referensi mempunyai pertumbuhan menonjol, namun pada wilayah studi belum menonjol.

c. Klasifikasi 3, yaitu nilai $R P_{R}(-)$ dan $R P_{S}(+)$ berarti kegiatan tersebut pada wilayah referensi mempunyai pertumbuhan tidak menonjol sementara pada wilayah studi termasuk menonjol.

d. Klasifikasi 4, yaitu nilai $R P_{R}(-)$ dan $R P_{S}(-)$ berarti kegiatan tersebut pada wilayah referensi dan wilayah studi mempunyai pertumbuhan rendah.

\section{ANALISIS SHIFT SHARE}

Analisis Shift Share merupakan teknik dalam menganalisis pertumbuhan ekonomi suatu daerah sebagai perubahan atau peningkatan suatu indikator pertumbuhan perekonomian suatu wilayah dalam kurun waktu tertentu [3]. Tujuan analisis Shift Share adalah untuk menganalisis perubahan struktur ekonomi daerah relatif terhadap struktur ekonomi wilayah administratif yang lebih tinggi sebagai pembanding[6].

1. Dampak nyata pertumbuhan ekonomi wilayah studi

$$
D_{i j}=N_{i j}+M_{i j}+C_{i j}
$$

2. Pengaruh pertumbuhan ekonomi referensi

$$
N_{i j}=E_{i j} \times r_{R}
$$

3. Pengaruh bauran industri (proportional shift)

$$
M_{i j}=E_{i j}\left(r_{i R}-r_{R}\right)
$$

4. Pengaruh keunggulan kompetitif (differential shift)

$$
C_{i j}=E_{i j}\left(r_{i j}-r_{R}\right)
$$

dimana:

$$
\begin{aligned}
& r_{R}=\left(E_{R, t}-E_{R, t-1}\right) / E_{R, t-1} \\
& r_{i R}=\left(E_{i, R, t}-E_{i, R, t-1}\right) / E_{i, R, t-1} \\
& r_{i j}=\left(E_{i, j, t}-E_{i, j, t-1}\right) / E_{i, j, t-1}
\end{aligned}
$$

Perubahan nyata pertumbuhan sektor ekonomi $i$ di Kota Pontianak dinotasikan dengan $D_{i j}, N_{i j}$ adalah komponen pengaruh pertumbuhan ekonomi Kalimantan Barat untuk sektor $i$ di Kota Pontianak, $M_{i j}$ adalah pengaruh bauran industri (proportional shift) sektor ekonomi $i$ di Kota Pontianak, dan $C_{i j}$ adalah pengaruh keunggulan kompetitif (differential shift) sektor ekonomi $i$ di Kota Pontianak.

Jika nilai Shift Share $\geq 1$ dengan kriteria (+), maka pertumbuhan sektor pada wilayah studi lebih cepat dibandingkan dengan pertumbuhan sektor pada wilayah referensi. Jila nilai Shift Share < 1 dengan kriteria (-), maka pertumbuhan sektor pada wilayah studi lebih lambat dibandingkan dengan pertumbuhan sektor pada wilayah referensi. 
Analisis Overlay merupakan suatu teknik yang digunakan untuk mengambil sebuah kesimpulan dengan menggabungkan beberapa hasil analisis[3]. Hasil analisis yang digabungkan yaitu $L Q$ dan $D L Q$ yang menunjukkan kontribusi, kemudian analisis MRP menunjukkan pertumbuhan. Analisis Overlay memiliki empat prediksi yaitu:

a. Pertumbuhan (+) dan kontribusi (+), menunjukkan sektor ekonomi sangat dominan pertumbuhan dan kontribusinya.

b. Pertumbuhan (+) dan kontribusi (-), menunjukkan sektor ekonomi dominan pertumbuhan tetapi kontribusinya kecil. Sektor tersebut perlu lebih ditingkatkan kontribusinya untuk menjadi kegiatan yang dominan.

c. Pertumbuhan (-) dan kontribusinya (+), menunjukkan sektor ekonomi pertumbuhannya kecil tetapi kontribusinya besar. Sektor tersebut memungkinkan sedang mengalami penurunan.

d. Pertumbuhan (-) dan kontribusinya (-), menunjukkan sektor ekonomi tidak potensial baik dari kriteria pertumbuhan maupun dari kontribusi.

\section{HASIL DAN PEMBAHASAN}

Penelitian ini menggunakan metode studi kasus, dimana dalam menggunakan metode ini dilakukan identifikasi yang mendalam terhadap sesuatu keadaan. Menggunakan cara yang sistematis dalam pengamatan, pengumpulan data, analisis informasi dan pelaporan hasil. Jenis data yang digunakan pada penelitian ini adalah data sekunder yang diperoleh dari Badan Pusat Statistik. Data yang di analisis adalah data PDRB berdasarkan lapangan usaha atas dasar harga konstan Kota Pontianak dan Kalimantan Barat pada tahun 2012 sampai dengan 2016 dalam satuan juta rupiah.

Perkembangan sektor-sektor ekonomi di Kota Pontianak menunjukkan perkembangan dengan kriteria (+) yang berarti sektor ekonomi ini dalam kurun waktu lima tahun mengalami pergerakan dengan memberikan kontribusi yang besar terhadap perekonomian Kota Pontianak. Kontribusi ini secara persentase menggambarkan bahwa pembangunan di daerah ini mengalami peningkatan dan penurunan pada beberapa sektor. Sektor yang mengalami penurunan di antaranya sektor Informasi dan Komunikasi; sektor Industri Pengolahan; sektor Transportasi dan Pergudangan; sektor Administrasi Pemerintahan, Pertahanan dan Jaminan Sosial Wajib; sektor Jasa Keuangan dan Asuransi; dan sektor Pengadaan Listrik dan Gas yang dapat dilihat pada Tabel 2.

Tabel 2 Rasio Perkembangan Ekonomi Kota Pontianak

\begin{tabular}{clccc}
\hline \multirow{2}{*}{ No. } & \multicolumn{1}{c}{ Lapangan Usaha } & \multicolumn{2}{c}{ Rasio (\%) } & \multirow{2}{*}{ Selisih } \\
\cline { 2 - 3 } & \multicolumn{2}{c}{$\mathbf{2 0 1 2}$} & $\mathbf{2 0 1 6}$ & \\
\hline \multirow{2}{*}{5} & Pengadaan Air, Pengelolaan Sampah, & 50,34 & 52,89 & \\
& Limbah dan Daur Ulang & & & \\
15 & Jasa Pendidikan & 29,38 & 30,61 & 1,23 \\
9 & Penyediaan Akomodasi dan Makan Minum & 26,95 & 28,03 & 1,08 \\
13 & Jasa Perusahaan & 25,89 & 26,94 & 1,05 \\
12 & Real Estat & 16,92 & 17,96 & 1,04 \\
16 & Jasa Kesehatan dan Kegiatan Sosial & 21,53 & 22,29 & 0,76 \\
6 & Konstruksi & 24,9 & 25,55 & 0,65 \\
7 & Perdagangan Besar dan Eceran; Reparasi & 23,95 & 24,05 & 0,1 \\
1 & Mobil dan Sepeda Motor & & & \\
1 & Pertanian, Kehutanan, dan Perikanan & 1,28 & 1,29 & 0,01 \\
17 & Jasa Lainnya & 35,51 & 35,51 & 0 \\
10 & Informasi dan Komunikasi & 20,49 & 20,1 & $-0,39$ \\
3 & Industri Pengolahan & 19,32 & 18,91 & $-0,41$ \\
8 & Transportasi dan Pergudangan & 42,86 & 42,39 & $-0,47$ \\
14 & Administrasi Pemerintahan, Pertahanan dan & 20,55 & 18,96 & $-1,59$ \\
& Jaminan Sosial Wajib & & & \\
11 & Jasa Keuangan dan Asuransi & 44,62 & 41,78 & $-2,84$ \\
4 & Pengadaan Listrik dan Gas & 28,84 & 22,68 & $-6,16$
\end{tabular}


2 Pertambangan dan Penggalian

$\begin{array}{llll}\text { PDRB } & 18,06 & 18,45 & 0,39\end{array}$

Sumber: BPS, Data Sekunder yang diolah

Langkah awal dari pengerjaan adalah mengklasifikasikan sektor ekonomi dengan klasifikasi sektor ekonomi berdasarkan sektor tumbuh cepat, sektor tertekan, sektor sedang tumbuh, dan sektor relatif tertinggal. Hasil klasifikasi Typology Klassen adalah sebagai berikut:

Tabel 3 Hasil Klasifikasi Typology Klassen Sektor Ekonomi Kota Pontianak

\begin{tabular}{|c|c|c|}
\hline & $y_{i j}>y_{i R}$ & $y_{i j}<y_{i R}$ \\
\hline & Kuadran 1 (Sektor tumbuh cepat) & Kuadran 3 (Sektor sedang tumbuh) \\
\hline$g_{i j}>G_{i}$ & $\begin{array}{ll}\text { - } & \text { Konstruksi } \\
\text { - } & \text { Perdagangan Besar dan Eceran; Reparasi } \\
& \text { Mobil dan Sepeda Motor } \\
\text { - } & \text { Penyediaan Akomodasi Makan dan } \\
& \text { Minum } \\
\text { - } & \text { Jasa Perusahaan } \\
\text { - } & \text { Jasa Pendidikan } \\
\text { - } & \text { Jasa Kesehatan dan Kegiatan Sosial }\end{array}$ & $\begin{array}{l}\text { - Pertanian, Kehutanan, dan } \\
\text { Perikanan } \\
\text { - Real Estate }\end{array}$ \\
\hline & Kuadran 2 (Sektor tertekan) & Kuadran 4 (Sektor relatif tertinggal) \\
\hline$g_{i j}<G_{i}$ & $\begin{array}{ll} & \text { Industri Pengolahan } \\
\text { - } & \text { Pengadaan Listrik dan Gas } \\
\text { - } & \text { Transportasi dan Pergudangan } \\
\text { - } & \text { Informasi dan Komunikasi } \\
\text { - } & \text { Jasa Keuangan dan Asuransi } \\
\text { - } & \text { Administrasi Pemerintahan, Pertahanan } \\
& \text { dan Jaminan Sosial Wajib } \\
\text { - } & \text { Jasa Lainnya }\end{array}$ & \\
\hline
\end{tabular}

Sumber: BPS, Data Sekunder yang diolah

Dilanjutkan dengan analisis $L Q$ yaitu dengan membandingkan besar peranan suatu sektor di Kota Pontianak terhadap besarnya peranan sektor tersebut di provinsi Kalimantan Barat. Selanjutnya dilakukan analisis $D L Q$ yang dihitung dengan cara membandingkan nilai sektor ekonomi Kota Pontianak dengan sektor ekonomi yang sama di tingkat wilayah yang lebih luas wilayah sebarannya yaitu Kalimantan Barat. Hasil perhitungan sektor lapangan usaha Kota Pontianak di Kalimantan Barat menggunakan $L Q$ dan $D L Q$ sebagai berikut:

Tabel 4 Hasil Analisis $L Q$ dan $D L Q$ Sektor Ekonomi Kota Pontianak

\begin{tabular}{|c|c|c|c|c|c|c|}
\hline \multirow{2}{*}{ No. } & \multirow{2}{*}{ Lapangan Usaha } & \multicolumn{2}{|c|}{ Rata-rata } & \multirow{2}{*}{ Kategori } & \multirow{2}{*}{$L Q$} & \multirow{2}{*}{$D L Q$} \\
\hline & & LQ & DLQ & & & \\
\hline 5 & $\begin{array}{l}\text { Pengadaan Air, Pengelolaan Sampah, } \\
\text { Limbah dan Daur Ulang }\end{array}$ & 2,83 & 3,65 & Basis/ Berpotensi & + & + \\
\hline 16 & Jasa Kesehatan dan Kegiatan Sosial & 1,2 & 3,3 & Basis/ Berpotensi & + & + \\
\hline 13 & Jasa Perusahaan & 1,45 & 2,75 & Basis/ Berpotensi & + & + \\
\hline 15 & Jasa Pendidikan & 1,64 & 2,46 & Basis/ Berpotensi & + & + \\
\hline 9 & $\begin{array}{l}\text { Penyediaan Akomodasi dan Makan } \\
\text { Minum }\end{array}$ & 1,51 & 2,49 & Basis/ Berpotensi & + & + \\
\hline 12 & Real Estate & 0,96 & 2,95 & Basis/ Berpotensi & - & + \\
\hline 7 & $\begin{array}{l}\text { Perdagangan Besar dan Eceran; } \\
\text { Reparasi Mobil dan Sepeda Motor }\end{array}$ & 1,32 & 2,13 & Basis/ Berpotensi & + & + \\
\hline 8 & Transportasi dan Pergudangan & 2,34 & 1,07 & Basis/ Berpotensi & + & + \\
\hline 6 & Konstruksi & 1,38 & 1,78 & Basis/ Berpotensi & + & + \\
\hline 17 & Jasa Lainnya & 1,95 & 0,94 & Basis/ Kurang Berpotensi & + & - \\
\hline 11 & Jasa Keuangan dan Asuransi & 2,37 & 0,37 & Basis/ Kurang Berpotensi & + & - \\
\hline 3 & Industri Pengolahan & 1,05 & 0,91 & Basis/ Kurang Berpotensi & - & - \\
\hline 10 & Informasi dan Komunikasi & 1,11 & 0,84 & Basis/ Kurang Berpotensi & + & - \\
\hline 14 & $\begin{array}{l}\text { Administrasi Pemerintahan, Pertahanan } \\
\text { dan Jaminan Sosial Wajib }\end{array}$ & 1,08 & 0,64 & Basis/ Kurang Berpotensi & - & - \\
\hline 4 & Pengadaan Listrik dan Gas & 1,41 & 0,15 & Basis/ Kurang Berpotensi & + & - \\
\hline
\end{tabular}


1 Pertanian, Kehutanan, dan Perikanan $\quad 0,07 \quad 1,45 \quad$ Non Basis/ Berpotensi $\quad-\quad+$ 2 Pertambangan dan Penggalian

Kemudian dilanjutkan dengan analisis MRP yaitu dengan melihat sektor ekonomi mana yang tingkat pertumbuhannya di Kota Pontianak yang dominan di Kalimantan Barat. Berikut hasil analisis MRP yang dapat dilihat di Tabel 5.

Tabel 5 Hasil Analisis MRP Sektor Ekonomi Kalimantan Barat dan Kota Pontianak

\begin{tabular}{|c|c|c|c|c|c|}
\hline \multirow{2}{*}{ No. } & \multirow{2}{*}{ Lapangan Usaha } & \multicolumn{2}{|c|}{ Kalimantan Barat } & \multicolumn{2}{|c|}{ Kota Pontianak } \\
\hline & & $\boldsymbol{R} \boldsymbol{P}_{R}$ & Kriteria & $\boldsymbol{R} \boldsymbol{P}_{S}$ & Kriteria \\
\hline 5 & $\begin{array}{l}\text { Pengadaan Air, Pengelolaan Sampah, } \\
\text { Limbah dan Daur Ulang }\end{array}$ & 29,09 & + & 1,26 & + \\
\hline 12 & Real Estate & 21,06 & + & 1,1 & + \\
\hline 16 & Jasa Kesehatan dan Kegiatan Sosial & 28 & + & 1,08 & + \\
\hline 15 & Jasa Pendidikan & 23,03 & + & 1,04 & + \\
\hline 9 & Penyediaan Akomodasi dan Makan Minum & 17,01 & + & 0,96 & - \\
\hline 13 & Jasa Perusahaan & 14,8 & + & 0,91 & - \\
\hline 1 & Pertanian, Kehutanan, dan Perikanan & 26,92 & + & 0,9 & - \\
\hline 17 & Jasa Lainnya & 25,7 & + & 0,89 & - \\
\hline 7 & $\begin{array}{l}\text { Perdagangan Besar dan Eceran; Reparasi } \\
\text { Mobil dan Sepeda Motor }\end{array}$ & 16,88 & + & 0,83 & - \\
\hline 8 & Transportasi dan Pergudangan & 15,17 & + & 0,77 & - \\
\hline 3 & Industri Pengolahan & 19,84 & + & 0,74 & - \\
\hline 6 & Konstruksi & 10,18 & + & 0,71 & - \\
\hline 10 & Informasi dan Komunikasi & 7,04 & + & 0,62 & - \\
\hline 11 & Jasa Keuangan dan Asuransi & 9,23 & + & 0,56 & - \\
\hline 14 & $\begin{array}{l}\text { Administrasi Pemerintahan, Pertahanan dan } \\
\text { Jaminan Sosial Wajib }\end{array}$ & 17,37 & + & 0,51 & - \\
\hline 4 & Pengadaan Listrik dan Gas & 5,67 & + & 0,38 & - \\
\hline 2 & Pertambangan dan Penggalian & 17,72 & + & 0 & - \\
\hline
\end{tabular}

Sumber: BPS, Data Sekunder yang diolah

Kemudian dilanjutkan dengan analisis Shift Share yaitu dengan melihat dampak nyata pertumbuhan ekonomi di Kota Pontianak, dengan memperhitungkan pengaruh pertumbuhan ekonomi referensi, pengaruh bauran industri, dan pengaruh keunggulan kompetitif. Berikut hasil analisis Shift Share yang dapat dilihat di Tabel 6.

Tabel 6 Rata-rata Hasil Analisis Shift Share Sektor Lapangan Usaha Kota Pontianak

\begin{tabular}{clrrrr}
\hline No. Lapangan Usaha & \multicolumn{1}{c}{$\boldsymbol{N}_{\boldsymbol{i} \boldsymbol{j}}$} & \multicolumn{1}{c}{$\boldsymbol{M}_{\boldsymbol{i} \boldsymbol{j}}$} & \multicolumn{1}{c}{$\boldsymbol{C}_{\boldsymbol{i} \boldsymbol{j}}$} & \multicolumn{1}{c}{$\boldsymbol{D}_{\boldsymbol{i} \boldsymbol{j}}$} \\
\hline 1 & Pertanian, Kehutanan, dan Perikanan & 73381,26 & $-26272,43$ & $-24134,03$ & 19145,67 \\
2 & Pertambangan dan Penggalian & - & - & - & - \\
3 & Industri Pengolahan & 787036,15 & $-103592,20$ & $-191379,22$ & 410053,94 \\
4 & Pengadaan Listrik dan Gas & 5329,49 & 10321,08 & 2010,68 & 14717,71 \\
5 & Pengadaan Air, Pengelolaan Sampah, & 18224,79 & $-7149,34$ & $-2570,41$ & 7087,53 \\
& Limbah dan Daur Ulang & & & & \\
6 & Konstruksi & 680499,70 & 387881,95 & 493261,11 & 1301368,96 \\
7 & Perdagangan Besar dan Eceran; Reparasi & 888918,61 & 21575,09 & 42310,17 & 794003,22 \\
& Mobil dan Sepeda Motor & & & & \\
8 & Transportasi dan Pergudangan & 438524,20 & 58249,84 & 31508,01 & 440235,04 \\
9 & Penyediaan Akomodasi dan Makan & 154117,88 & $-977,71$ & 32260,06 & 154500,19 \\
& Minum & & & & \\
10 & Informasi dan Komunikasi & 205712,67 & 257150,77 & 231240,18 & 578419,68 \\
11 & Jasa Keuangan dan Asuransi & 380848,69 & 276054,12 & 128345,78 & 654373,82 \\
12 & Real Estate & 127118,79 & $-25928,27$ & 14381,06 & 96309,65 \\
13 & Jasa Perusahaan & 30869,72 & 3858,43 & 10755,04 & 37902,66 \\
14 & Administrasi Pemerintahan, Pertahanan & 229322,17 & $-7802,08$ & $-102693,77$ & 99021,94 \\
& dan Jaminan Sosial Wajib & & & & 185654,65 \\
15 & Jasa Pendidikan & 316593,91 & $-80824,11$ & $-12984,22$ & 25663,27 \\
16 & Jasa Kesehatan dan Kegiatan Sosial & 78545,63 & $-30726,90$ & $-17022,81$ & 29333,24 \\
17 & Jasa Lainnya & 93875,19 & $-29309,97$ & $-29365,33$ & \\
\hline
\end{tabular}

Sumber: BPS, Data Sekunder yang diolah 
Hasil dari perhitungan $D_{i j}$ menunjukkan dampak nyata pertumbuhan ekonomi di Kota Pontianak bahwa dari semua sektor dengan kriteria (+), yang berarti nilai pendapatan atau PDRB Kota Pontianak mengalami kenaikan kinerja ekonomi. Sektor yang memiliki dampak nyata pertumbuhan ekonomi di Kota Pontianak adalah sektor Konstruksi dengan jumlah Rp 1,301,368,96 juta dan memiliki keunggulan kompetitif $\left(C_{i j}\right)$ yang tinggi yaitu $\mathrm{Rp} 493261,11$ juta. Sektor ekonomi di Kota Pontianak menunjukkan pertumbuhan, berkembang pesat dan dominan serta layak untuk dikembangkan. Kemudian terdapat sektor Perdagangan Besar dan Eceran; sektor Jasa Keuangan dan Asuransi; sektor Informasi dan Komunikasi; sektor Transportasi dan Pergudangan; sektor Jasa Perusahaan; dan sektor Pengadaan Listrik dan Gas memiliki pertumbuhan yang cepat serta memberikan pengaruh positif kepada perekonomian Kota Pontianak.

Analisis Overlay menggabungkan hasil analisis $L Q, D L Q$, dan MRP untuk menentukan sektor unggulan di Kota Pontianak. Gabungan hasil analisis menunjukkan hubungan antar metode, berisi sektor apa saja yang akan menjadi masukan serta perhatian khusus pemerintah daerah dalam meningkatkan pendapatan daerah. Sektor yang memiliki kriteria (+) terbanyak dalam metode analisis yang digunakan, Berikut hasil analisis Overlay sektor perekonomian Kota Pontianak tahun 2012-2016.

Tabel 7 Analisis Overlay Sektor Lapangan Usaha Kota Pontianak Tahun 2012-2016

\begin{tabular}{clccc}
\hline No. & \multicolumn{1}{c}{ Lapangan Usaha } & LQ & DLQ & MRP \\
\hline 5 & Pengadaan Air, Pengelolaan Sampah, & + & + & + \\
\multicolumn{1}{c}{ Limbah dan Daur Ulang } & & & \\
16 & Jasa Kesehatan dan Kegiatan Sosial & + & + & + \\
12 & Real Estate & - & + & + \\
13 & Jasa Perusahaan & + & + & - \\
9 & Penyediaan Akomodasi dan Makan Minum & + & + & - \\
15 & Jasa Pendidikan & + & + & - \\
7 & Perdagangan Besar dan Eceran; Reparasi & + & + & - \\
\multicolumn{7}{c}{ Mobil dan Sepeda Motor } & & & \\
6 & Konstruksi & + & + & - \\
1 & Pertanian, Kehutanan, dan Perikanan & - & + & - \\
8 & Transportasi dan Pergudangan & + & + & - \\
17 & Jasa Lainnya & + & - & + \\
3 & Industri Pengolahan & - & - & - \\
10 & Informasi dan Komunikasi & + & - & - \\
14 & Administrasi Pemerintahan, Pertahanan & - & - & - \\
& dan Jaminan Sosial Wajib & & & - \\
11 & Jasa Keuangan dan Asuransi & + & - & - \\
4 & Pengadaan Listrik dan Gas & + & - & - \\
2 & Pertambangan dan Penggalian & - & - & - \\
\hline
\end{tabular}

Sumber: BPS, Data Sekunder yang diolah

Hasil analisis Overlay untuk sektor Pengadaan Air, Pengelolaan Sampah, Limbah dan Daur Ulang; dan sektor Jasa Kesehatan dan Kegiatan Sosial merupakan sektor yang banyak berkontribusi di wilayah Kalimantan Barat. Sektor lapangan usaha tersebut berpotensi untuk tetap menjadi sektor yang basis di masa mendatang dan memiliki pertumbuhan yang tinggi sehingga menjadi sektor yang unggul di Kota Pontianak dan berperan di perekonomian Kalimantan Barat. Sektor Real Estate merupakan sektor lapangan usaha yang memiliki tingkat pertumbuhan yang tinggi dan berpotensi akan menjadi sektor yang basis namun posisi sektor ini tidak terlalu dominan di sektor perekonomian yang sama di Kalimantan Barat.

Sektor Jasa Perusahaan; sektor Penyediaan Akomodasi dan Makan Minum; sektor Jasa Pendidikan; sektor Perdagangan Besar dan Eceran, Reparasi Mobil dan Sepeda Motor; sektor Konstruksi; dan sektor Transportasi dan Pergudangan merupakan sektor basis yang dominan di Kota Pontianak serta berkontribusi di sektor perekonomian yang sama di Kalimantan Barat. Sektor tersebut memiliki kecenderungan akan menjadi sektor yang akan tetap basis di masa mendatang, namun memungkinkan sedang mengalami penurunan. Sektor Jasa Lainnya merupakan sektor lapangan usaha yang memiliki pertumbuhan dan kontribusi yang besar di Kota Pontianak juga di sektor yang sama di wilayah Kalimantan Barat, namun sektor ini tidak memiliki kecenderungan untuk tetap menjadi sektor yang 
basis di masa mendatang. Sektor tersebut dapat diajukan sebagai usulan Pemerintah Daerah supaya dapat diperhatikan.

Sektor Informasi dan Komunikasi; sektor Jasa Keuangan dan Asuransi; dan sektor Pengadaan Listrik dan Gas merupakan sektor lapangan usaha yang memiliki kontribusi yang besar di Kota Pontianak dan di sektor yang sama di wilayah Kalimantan Barat. Namun, sektor tersebut tidak memiliki kecenderungan untuk menjadi sektor yang basis di masa mendatang dan pertumbuhan sektor yang rendah sehingga dapat diajukan sebagai usulan Pemerintah Daerah supaya dapat diperhatikan.

\section{KESIMPULAN}

Hasil analisis Typology Klassen sektor perekonomian di Kota Pontianak pada sektor Pengadaan Air, Pengelolaan Sampah, Limbah dan Daur Ulang; dan sektor Jasa Kesehatan dan Kegiatan Sosial tahun 2012-2016 menunjukkan sektor tumbuh cepat (Kuadran 1). Laju pertumbuhan dan pendapatan perkapita pada sektor lebih tinggi dari rata-rata wilayah provinsi Kalimantan Barat.

Berdasarkan hasil analisis Overlay, sektor Pengadaan Air, Pengelolaan Sampah, Limbah dan Daur Ulang; dan sektor Jasa Kesehatan dan Kegiatan Sosial merupakan sektor unggulan di Kota Pontianak. Sektor tersebut menunjukkan pertumbuhan dan kontribusi yang sangat besar terhadap pembentukan PDRB dan pembangunan di Kota Pontianak. Sektor layak dikembangkan serta dapat menjadi perhatian khusus pemerintah daerah dalam meningkatkan pendapatan daerah.

\section{DAFTAR PUSTAKA}

[1]. Dhyatmika, K, W. Analisis Ketimpangan Pembangunan Provinsi Banten Pasca Pemekaran. Diponegoro Journal Of Economics. 2013; 2(2), 1-8.

[2]. Badan Pusat Statistik. https://kalbar.bps.go.id

[3]. Basuki, A, T., \& Gayatri, U. Penentu Sektor Unggulan dalam Pembangunan daerah: Studi Kasus di Kabupaten Ogan Komering Ilir. Jurnal Ekonomi \& Studi Pembangunan. 2009; 10(1), 34-50.

[4]. Santoso, M, F. Identifikasi Potensi Sektor Ekonomi Basis Dan Non Basis Kota Kediri Tahun 2009-2013. Edisi Yudisium 2015. 2015; 3(2), 1-8.

[5]. Riantika, Ida. Penentuan Prioritas Pembangunan Melalui Analisis Sektor-Sektor Potensial Di Kabupaten Gianyar. E-Jurnal EP Unud, 2017; 6 [5], 1185-1211, ISSN: 2303-0178.

[6]. Wahyuningtyas, R. Analisis Sektor Unggulan Menggunakan Data PDRB. Jurnal Gaussian. 2013; 2(3), 219-228.

DINI ADIYATIN

NEVA SATYAHADEWI

HENDRA PERDANA
: Jurusan Matematika FMIPA UNTAN, Pontianak diniadiya@gmail.com

: Jurusan Matematika FMIPA UNTAN, Pontianak neva.satya@math.untan.ac.id

: Jurusan Matematika FMIPA UNTAN, Pontianak hendra.perdana@math.untan.ac.id 